\begin{tabular}{|c|c|}
\hline LIN & Jurnal LINK, 17 (2), 2021, 129 - 134 \\
\hline 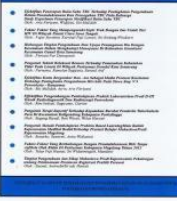 & $\begin{array}{c}\text { DOI: } 10.31983 / \text { link.v17i2.7783 } \\
\text { http://ejournal.poltekkes-smg.ac.id/ojs/index.php/link }\end{array}$ \\
\hline
\end{tabular}

\title{
PEMBERDAYAAN WARGA DENGAN “JOGO KELUARGA JOGO TONGGO DARI PENYEBARAN COVID-19"
}

\author{
M. Choiroel Anwar ${ }^{1}$; Gatot Murti Wibowo²)* \\ 1, 2 Jurusan Magister Terapan Imaging Diagnostik ; Poltekkes Kemenkes Semarang \\ Jl. Tirto Agung ; Pedalangan ; Banyumanik ; Semarang
}

\begin{abstract}
Abstrak
Tingginya masalah kesehatan saat ini mengindikasikan promosi kesehatan dan pencegahan kurang berkontribusi dalam meningkatkan derajat kesehatan. Promosi kesehatan mengenai penanganan Covid19 belum dilakukan di Desa Batursari, sehingga perlu dilakukan promosi kesehatan. Tujuan pengabdian masyarakat memberdayakan dan menggerakkan masyarakat Desa Batursari, RW 16, Mranggen, Demak berperilaku hidup sehat sesuai protokol pencegahan Covid-19. Metode yang digunakan memadukan beberapa kegiatan yaitu edukasi, penyuluhan dan pelatihan, pemeriksaan kesehatan (tanda vital dan status kesehatan gizi) dan survei mandiri monitoring status kesehatan (google forms), dan pemberian bantuan. Hasilnya pengabmas melalui promosi dan monitoring harian dilakuakan oleh tim pengabmas, kader PKK pencegahan Covid-19 dan sampel subyek dengan Whats App Group terjadi peningkatan pengetahuan yang berdampak pada pola perilaku hidup bersih dan sehat.
\end{abstract}

Kata kunci: Covid-19; hidup sehat ; promosi kesehatan

\begin{abstract}
[EMPOWERMENT OF CITIZENS WITH “TAKE CARE OF YOUR FAMILY, TAKE CARE OF YOUR NEIGHBORS FROM COVID-19"] The current high number of health problems indicates that health promotion and prevention do not contribute to improving health status. The purpose of community service is to empower and mobilize the people of Batursari Village, RW 16, Mranggen, Demak to live a healthy life according to the Covid-19 prevention protocol. The methods used are education, training, health checks (vital signs and nutritional health status), independent surveys of health status, and providing assistance. The result is that community service providers through promotions and daily monitoring are carried out by the community service team, PKK cadres of Covid-19 prevention and a sample of subjects with Whats App Group there is an increase in knowledge that has an impact on clean and healthy living behavior patterns.
\end{abstract}

Keywords: Covid-19; healthy life ; health promotion

\section{Pendahuluan}

Politeknik Kesehatan Kemenkes Semarang sebagai salah satu institusi pendidikan di bawah naungan Kementerian Kesehatan dalam menjalankan perannya sesuai dengan Undang-Undang Nomor 12 Tahun 2012 Tentang Pendidikan Tinggi, Politeknik Kesehatan Kemenkes Semarang memiliki tugas pokok dan fungsi Tri Dharma Pendidikan Tinggi, yaitu pendidikan dan pengajaran, penelitian

\footnotetext{
*) Correspondence Author (Gatot Murti Wibowo)

E-mail: gatotmurtiw@gmail.com
}

serta pengabdian kepada masyarakat (Pemerintah Indonesia, 2012).

Pengabdian kepada masyarakat adalah salah satu kegiatan bagi mahasiswa dan dosen sebagai elemen inti perguruan tinggi dalam mengimplementasikan keilmuan yang dimiliki kepada masyarakat. Dengan kegiatan pengabdian kepada masyarakat, diharapkan kehidupan masyarakat dapat ikut tercerahkan oleh keilmuan yang dimiliki oleh insan-insan akademik. Secara garis besar terdapat 2 macam jenis kegiatan pengabdian kepada masyarakat, yaitu pertama yang bersifat internal, yaitu 
kegiatan-kegiatan yang direncanakan dalam program kegiatan akademik tahunan. Jenis yang kedua yaitu bersifat eksternal, yaitu suatu kegiatan pengabdian kepada masyarakat yang bersifat spontan dan insidental karena adanya permintaan kerja sama dari instansi lain (Direktorat Riset dan Pengabdian Kepada Masyarakat, 2018).

Kegiatan pengabdian kepada masyarakat (Pengabmas) yang dilaksanakan oleh Politeknik Kesehatan Kemenkes Semarang diikuti oleh warga Desa Batursari, Mranggen, Demak. Adapun kegiatan yang dilaksanakan dalam pengabdian kepada masyarakat mengusung topik utama mengenai pencegahan Covid-19.

Covid-19 merupakan penyakit menular yang disebabkan oleh jenis coronavirus yang baru ditemukan. Covid-19 dapat menyebar terutama dari orang ke orang melalui percikanpercikan dari hidung atau mulut yang keluar saat orang yang terinfeksi COVID-19 batuk, bersin atau berbicara (WHO, 2020). Pencegahan Covid-19 dapat dilakukan dengan beberapa cara diantaranya mencuci tangan dengan benar, menjaga jarak minimal 1 meter, dan menggunakan masker dengan benar (Kemenkes RI, 2021).

Pencegahan penyakit dan promosi kesehatan merupakan upaya esensial di saat masih tingginya kejadian penyakit menular juga diiringi dengan semakin meningkatnya masalah penyakit tidak menular. Semakin tingginya beban masalah kesehatan masyarakat saat ini mengindikasikan bahwa promosi kesehatan dan pencegahan yang telah ada kurang dapat berkontribusi dalam meningkatkan derajat kesehatan masyarakat. Banyak studi yang menemukan bahwa upaya promosi kesehatan dan pencegahan penyakit yang bersifat topdown dari pemerintah, kurang efektif bila dibandingkan dengan program yang berbasis (Rojali, 2019). Salah satu contohnya adalah pelaksanaan Promosi Kesehatan Rumah Sakit (PKRS) rumah sakit swasta di Tangerang Selatan, dimana penyelenggaraan PKRS masih belum optimal, walaupun telah ada dukungan dan komitmen pelaksana yang baik, akan tetapi adanya faktor lain yang mempengaruhi implementasi konsep tersebut seperti masih belum lengkapnya sumber daya yang dimiliki, komunikasi terkait aktivitas PKRS yang terjalin antar petugas masih kurang. Untuk dapat mencapai tujuan dari promosi kesehatan maka dibutuhkan realisasi dukungan dan komitmen menjadi suatu kebutuhan untuk mengimplementasikan promosi kesehatan secara optimal (Rae Febrian et al., 2020).

Promosi kesehatan juga berperan dalam mendukung pencegahan Covid-19 yang dicanangkan oleh pemerintah. Saat ini di Desa Batursari, belum dilakukan promosi kesehatan mengenai pencegahan Covid-19. Untuk itu perlu dilakukan inisiasi promosi kesehatan mengenai pencegahan Covid-19. Salah satu program inisiasi tersebut yaitu melalui kegiatan pengabdian kepada masyarakat dengan tema "Jogo Keluarga Jogo Tonggo Dari Covid-19". Dalam kegiatan pengabdian kepada masyarakat ini pencegahan Covid-19 di Desa Batursari dilakukan melalui pemberdayaan masyarakat.

Pemberdayaan masyarakat merupakan proses mengembangkan, memandirikan, menswadayakan, memperkuat posisi tawar menawar masyarakat lapisan bawah terhadap kekuatan-kekuatan penekan di segala bidang dan sektor kehidupan (Sutoro, 2002). Selain itu pemberdayaan masyarakat adalah suatu strategi yang digunakan dalam pembangunan masyarakat sebagai upaya untuk mewujudkan kemampuan dan kemandirian dalam kehidupan bermasyarakat, berbangsa dan bernegara (Pemerintah Indonesia, 2007).

Tujuan pemberdayaan masyarakat adalah memampukan dan memandirikan masyarakat terutama dari kemiskinan dan keterbelakangan / kesenjangan / ketidakberdayaan. Kemiskinan dapat dilihat dari indikator pemenuhan kebutuhan dasar yang belum mencukupi/layak. Keterbelakangan, misalnya produktivitas yang rendah, sumberdaya manusia yang lemah (Usman, 2004).

Tugas pemberdayaan masyarakat bisa dilakukan oleh banyak elemen pemerintah, perguruan tinggi, lembaga swadaya masyarakat, pers, partai politik, lembaga donor, aktoraktor masyarakat sipil, atau oleh organisasi masyarakat lokal sendiri (Sutoro, 2002). Ketika kemitraan mampu mendorong percepatan kemapanan ekonomi masyarakat berfungsi secara efektif, maka kemampuan dan kemandirian masyarakat dalam pembangunan akan dapat terwujud (Suwondo, 2005).

Sebagai bagian dari pengampu tugas untuk melakukan pemberdayaan masyarakat, Politeknik Kesehatan Kemenkes Semarang melalui kegiatan pengabdian kepada masyarakat mewujudkan pencegahan Covid-19 di Desa Batursari dengan cara penerapan perilaku hidup sehat sesuai protokol pencegahan Covid-19. 


\section{Metode}

Metode yang digunakan dalam pengabdian kepada masyarakat ini memadukan beberapa tahap kegiatan yaitu tahapan aktivitas edukasi, penyuluhan dan pelatihan, tahap aktivitas pemeriksaan kesehatan (tanda vital dan status kesehatan gizi) dan survei mandiri monitoring status kesehatan (google forms). Aktivitas Pemberian Bantuan alat PHBS berupa seperangkat tong cuci tangan.

Sasaran dari kegiatan pengabdian kepada masyarakat ini adalah masyarakat Desa Batursari, RW 16, Mranggen, Demak. Waktu dan pelaksanaan pengabdian kepada masyarakat dilaksanakan selama 4 bulan (Juni, Juli, Agustus, September 2020). Tahapan pelaksanaan diawali dengan perijinan yang dilakukan dan dilaksanakan pengabdi berserta mahasiswa tanggal 6, 8 dan 16 Juni 2020, persiapan kegiatan dan ruangan sosialisasi dan pemasangan MMT di pos kamling setiap RT di RW 16 Desa Batursari tanggal 4 Juli 2020, pengabmas dimulai tanggal 5 Juli 2020 Pukul 09.00 WIB di RW 16 Desa Batursari. Hasil evaluasi dari kegiatan pengabdian kepada masyarakat meningkatkan pemahaman masyarakat tentang berperilaku hidup sehat sesuai protokol pencegahan Covid19.

\section{Hasil dan Pembahasan}

Pada kegiatan pengabdian kepada masyarakat di Desa Batursari telah dilaksanakan kegiatan yaitu :

a. Edukasi tentang Covid-19

Acara kegiatan Pengabmas dimulai pada tanggal 5 Juli 2020 pukul 09.00 WIB. Acara diawali dengan dilakukannya pretest tentang Covid-19 menggunakan google form dengan 10 pertanyaan.

Selanjutnya penyampaian materi edukasi Covid-19 oleh narasumber dengan materi pengertian Covid-19, cara penularan Covid-19, dan cara pencegahan Covid-19. Setelah penyampaian materi selanjutnya dilakukan post test. Hasil pre-test dan post test adalah sebagai berikut :

1) Metode penyebaran Covid-19 didapatkan hasil $62,5 \%$ responden menjawab tahu dan $37,5 \%$ kurang tahu. Setelah dilakukan post test prosentase tahu yaitu $62,5 \%$ namun prosentase sangat tahu menjadi $25 \%$, dan kurang tahu turun menjadi $12,5 \%$. Sehingga pemaparan materi ini cukup memberikan perubahan hasil pada prosentase sangat tahu.

2) Gejala awal Covid-19 didapatkan hasil pre-test dari 8 responden terdapat $75 \%$ menyatakan tahu, $12,5 \%$ kurang tahu, dan $12,5 \%$ tidak tahu sedangkan hasil post test $62,5 \%$ tahu, $25 \%$ sangat tahu $12,5 \%$ kurang tahu. Dari hasil ini terdapat peningkatan dari tahu ke sangat tahu. Sedangkan untuk presentase kurang tahu tidak terjadi perubahan. Oleh sebab itu perubahan dari pre dan post belum menunjukkan hasil yang signifikan. Perlu adanya pemberian materi lagi dapat dilakukan menggunakan media whatsapp.

3) Pencegahan penyakit Covid-19 pre-test $87,5 \%$ tahu dan 12,5 kurang tahu. Untuk post test $50 \%$ tahu, 37,5\% sangat tahu, dan $12,5 \%$ kurang tahu. Dari pre dan post terdapat peningkatan dari tahu menjadi sangat tahu perubahanya $37,5 \%$. Terdapat perubahan namun untuk yang kurang tahu tidak terdapat perubahan sehingga belum dikatakan perubahan yang signifikan karena hanya terdapat peningkatan saja dari tahu menjadi lebih tahu.

4) Pentingnya gizi untuk meningkatkan kinerja sistem imun pre-test menunjukkan $75 \%$ tahu dan $25 \%$ kurang tahu sedangkan hasil post test cukup beragam $62,5 \%$ tahu, $12,5 \%$ sangat tahu, $12,5 \%$ ragu-ragu, dan $12,5 \%$ kurang tahu. Dari hasil post test dan pre-test memberikan dampak kenaikan pengetahuan yang memberikan dampak positif.

5) Pentingnya vitamin untuk menjaga daya tahan tubuh terdapat peningkatan hasil menjadi sangat tahu sebanyak $25 \%$.

6) Prosedur cuci tangan yang benar menunjukan $75 \%$ tahu, $12,5 \%$ kurang tahu dan $12,5 \%$ tidak tahu. Hasil post test terdapat peningkatan menjadi $50 \%$ tahu, 37,5\% sangat tahu, dan 12,5\% kurang tahu. Namun karena prosentasi yang kurang tahu masih tetap 12,5\% mungkin perlu adannya penamabahan materi.

7) Penggunaan masker yang benar untuk hasi pre-test $87,5 \%$ tahu dan $12,5 \%$ kurang tahu. Hasil post test $50 \%$ menjadi sangat tahu, $37,5 \%$ tahu, dan $12,5 \%$ tidak tahu. Materi yang disampaikan 
memberikan dampak postif karena penigkatan hasil grafik memuaskan.

8) Etika batuk yang benar menunjukan hasil pre-test $62,5 \%$ tahu, $25 \%$ kurang tahu, dan $12,5 \%$ tidak tahu. Sedangkan hasil post test $50 \%$ tahu, $37,5 \%$ sangat tahu, dan $12,5 \%$ kurang tahu. Walaupun terdapat peningkatan hasil dari responden tetapi masih terdapat presentase yang kurang tahu 12,5\% maka perlu adanya edukasi yang lebih mendalam lagi.

9) Untuk hasil pre-test mengenai pentingnya beraktifitas di rumah ada $62,5 \%$ tahu, 25\% tidak tahu, dan $12,5 \%$ tidak tahu. Hasil post testnya cukup baik $75 \%$ tahu, $12,5 \%$ sangat tahu, dan $12,5 \%$ kurang tahu.

10)Hasil pre-test mengenai protokol pencegahan sebanyak $75 \%$ tahu dan $25 \%$ kurang tahu. Hasil post test $75 \%$ tahu, $12,5 \%$ sangat tahu, dan $12,5 \%$ kurang tahu.

Berdasarkan data yang telah diperoleh tersebut, diketahui terdapat peningkatan pengetahuan kader tentang Covid-19 setelah diberikan edukasi (Tabel 1.).

Tabel 1. Pre dan Post Test Edukasi Covid-19

\begin{tabular}{lccc}
\hline \multicolumn{1}{c}{ Indikator } & $\begin{array}{c}\text { Tingkat } \\
\text { Pre-test } \\
\text { (tahu) }\end{array}$ & $\begin{array}{c}\text { Tingkat } \\
\text { Post-test } \\
\text { (sangat } \\
\text { tahu) }\end{array}$ & $\begin{array}{c}\text { Tingkat } \\
\text { Post-test } \\
\text { (tahu) }\end{array}$ \\
\hline $\begin{array}{l}\text { Metode penyebaran } \\
\text { Covid }\end{array}$ & $62.5 \%$ & $25 \%$ & $62.5 \%$ \\
\hline Gejala Covid & $75 \%$ & $25 \%$ & $62.5 \%$ \\
\hline Pencegahan Covid & $87.5 \%$ & $37.5 \%$ & $50 \%$ \\
\hline Asupan gizi (Imun) & $75 \%$ & $12.5 \%$ & $62.5 \%$ \\
\hline $\begin{array}{l}\text { Vitamun (Daya } \\
\text { tahan) }\end{array}$ & $75 \%$ & $25 \%$ & $62.5 \%$ \\
\hline $\begin{array}{l}\text { Cuci tangan pakai } \\
\text { sabun }\end{array}$ & $75 \%$ & $37.5 \%$ & $50 \%$ \\
\hline Penggunaan masker & $87,5 \%$ & $50 \%$ & $37.5 \%$ \\
\hline $\begin{array}{l}\text { Etika batuk yang } \\
\text { benar }\end{array}$ & $62.5 \%$ & $37.5 \%$ & $50 \%$ \\
\hline $\begin{array}{l}\text { Beraktifitas di } \\
\text { rumah saja }\end{array}$ & $62.5 \%$ & $12.5 \%$ & $75 \%$ \\
\hline $\begin{array}{l}\text { Protokol } \\
\text { pencegahan Covid }\end{array}$ & $75 \%$ & $12.5 \%$ & $75 \%$ \\
\hline
\end{tabular}

b. Pemeriksaan kesehatan (tanda vital dan status kesehatan gizi)

Kegiatan pengabdian kepada masyarakat selanjutnya adalah tes kesehatan untuk kader dan sampel subyek warga RW 16. Tes kesehatan ini bertujuan untuk mengetahui kondisi kesehatan khususnya sampel subyek dalam penelitian ini. Hasil tes secara umum cukup baik (Tabel 2.), hanya terdapat beberapa warga yang beresiko karena tekanan darah yang tinggi, gula darah dan obesitas (Gambar 1.).

Tabel 2. Pemeriksaan Kesehatan

\begin{tabular}{lccc}
\hline $\begin{array}{c}\text { Indikator } \\
\text { Kesehatan }\end{array}$ & $\begin{array}{c}\text { Cek } \\
\text { Kesehatan } \\
\mathbf{1}\end{array}$ & $\begin{array}{c}\text { Cek } \\
\text { Kesehatan } \\
\mathbf{2}\end{array}$ & $\begin{array}{c}\text { Cek } \\
\text { Kesehatan } \\
\mathbf{3}\end{array}$ \\
\hline Tensi & $<60 \%$ & $<60 \%$ & $<60 \%$ \\
\hline $\begin{array}{l}\text { Nilai suhu } \\
\text { normal }\end{array}$ & $>60 \%$ & $>60 \%$ & $>60 \%$ \\
\hline $\begin{array}{l}\text { Gula darah } \\
\text { normal }\end{array}$ & $>60 \%$ & $>60 \%$ & $>60 \%$ \\
\hline $\begin{array}{l}\text { BMI nilai } \\
\text { obesitas 1 }\end{array}$ & $>60 \%$ & $>60 \%$ & $<57,1 \%$ \\
\hline $\begin{array}{l}\text { Nilai lemak } \\
\text { Visceral }\end{array}$ & $>60 \%$ & $>60 \%$ & $<57,1 \%$ \\
normal & $>60 \%$ & $>60 \%$ & $>60 \%$ \\
\hline $\begin{array}{l}\text { Nilai } \\
\text { presentase } \\
\text { lemak yang } \\
\text { lebih dari }\end{array}$ & & & \\
$32 \%$ & & \\
\hline $\begin{array}{l}\text { Frekuensi } \\
\text { respirasi } \\
\text { normal }\end{array}$ & $<59 \%$ & $<59 \%$ & $>60 \%$ \\
\hline
\end{tabular}

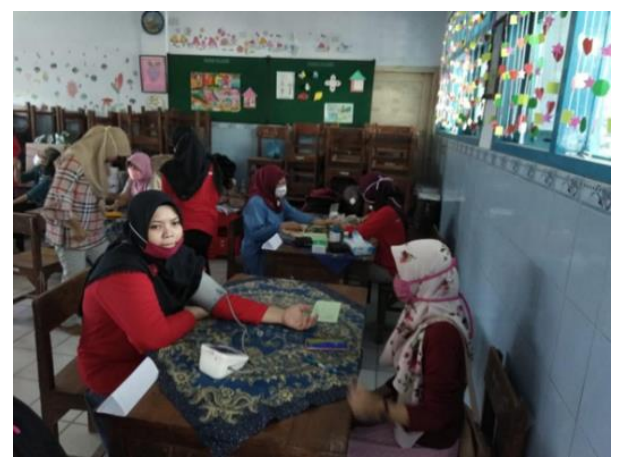

Gambar 1. Kegiatan Pemeriksaan Kesehatan

c. Edukasi Cuci Tangan dan Pemakaian Masker

Dalam kegiatan pengabdian kepada masyarakat juga dilakukan edukasi Hands on cuci tangan yang benar dan pemakaian masker yang tepat. Serta pemberitahuan tupoksi kader.

d. Pembagian Alat PHBS

Kegiatan berikutnya dilakukan pembagian alat PHBS (Perilaku Hidup Bersih dan Sehat) yang berupa seperangkat tong cuci tangan yang selanjutnya dibagikan pada tiap masing-masing RT 
untuk diletakkan di setiap pos kamling (Gambar 2.).

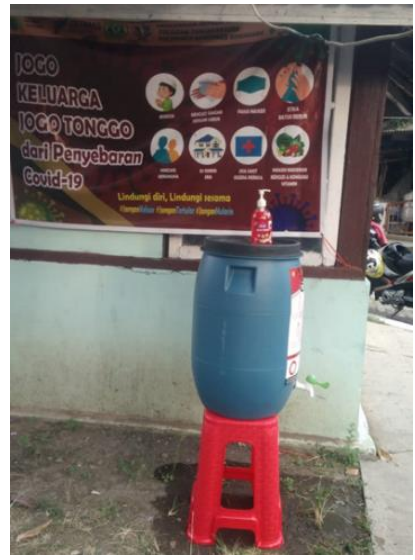

Gambar 2. Alat PHBS Berupa Tong Cuci Tangan

e. Promosi Kesehatan

Promosi kesehatan dilakukan bersama oleh tim pengabmas, kader PKK pencegah Covid-19 dan sampel subyek dengan memanfaatkan media Whats App Group (WAG). Langkah-langkah dalam melakukan promosi kesehatan diantaranya adalah tim dan kader berkomitmen menggunakan ikon WA pribadi dengan gambar nuansa bermasker sebagai bentuk komitmen dan promosi-edukasi bagi warga bahwa memakai masker adalah baik untuk melindungi diri, keluarga dan tetangga dari penularan Covid-19.

Langkah promosi selanjutnya berupa penyampaian konten-konten informasi dan komunikasi via WAG Kader Covid-19. Dalam WAG disampaikan tentang dialog, video, flayer ajakan, informasi pemerintah tentang laju petumbuhan atau penurunan wabah pandemik Covid-19 secara nasional maupun secara lokal (provinsi), termasuk karya video ajakan dan edukasi yang dibuat oleh tim pengabdi.

\section{f. Monitoring kesehatan}

Kegiatan monitoring kesehatan awal dilakukan pada saat pemeriksaan kesehatan. Selanjutnya monitoring kesehatan harian dilakukan oleh kader yang tergabung dalam WAG Kader Covid-19. Hasil dari monitoring kesehatan sampai dengan tahap akhir, kondisi status kesehatan kader dan sampel subyek masih dalam batas normal sehat.
Dalam kegiatan pengabdian kepada masyarakat ini terdapat kelebihan dan kekurangan sebagai berikut :

1) Kelebihan

Melalui kegiatan pengabdian kepada masyarakat dengan sasaran warga Desa Batursari memberikan dampak yang positif terhadap warga. Warga menjadi lebih paham tentang penularan Covid-19 dan cara pencegahannya, sehingga warga dapat menerapkan perilaku hidup sehat sesuai protokol pencegahan Covid-19.

2) Kekurangan

Dibutuhkan evaluasi secara berkala untuk mengetahui hasil dari pelaksanaan kegiatan pengabdian kepada masyarakat, seperti evaluasi perilaku hidup sehat sesuai protokol pencegahan Covid-19 tersebut apakah telah dilaksanakan dengan baik oleh warga Desa Batursari.

\section{Simpulan dan Saran}

Kegiatan pengabdian kepada masyarakat telah meningkatkan pemahaman warga Desa Batursari tentang perilaku hidup sehat sesuai protokol pencegahan Covid-19. Hal ini diketahui berdasarkan hasil dari pre dan post test dan juga melalui kegiatan monitoring kesehatan.

Kegiatan pengabdian kepada masyarakat ini diharapkan dapat memberikan dampak positif bagi warga Desa Batursari untuk selalu menjaga perilaku hidup sehat untuk pencegahan Covid-19 baik di lingkup keluarga maupun di lingkungan bermasyarakat.

Kegiatan pengabdian kepada masyarakat selanjutnya dapat berupa evaluasi dan monitoring terhadap perilaku hidup sehat sesuai protokol pencegahan Covid-19 yang telah terlaksana. Kegiatan evaluasi ini untuk mengetahui dampak dari perilaku hidup sehat yang telah dilaksanakan oleh warga Desa Batursari.

\section{Ucapan Terima Kasih}

Penelitian ini dapat dilaksanakan dengan baik berkat bantuan dari berbagai pihak, untuk itu peneliti mengucapkan terima kasih kepada UPPM Poltekkes Kemenkes Semarang dan warga Desa Batursari Mranggen Demak yang telah berkerja sama dengan baik dalam penelitian ini. 


\section{Daftar Pustaka}

Direktorat Riset dan Pengabdian Kepada Masyarakat (2018) Panduan Penilaian Kinerja Pengabdian Kepada Masyarakat Di Perguruan Tinggi. Jakarta. Available at: http://www.ristekdikti.go.id/kinerja_abdi mas.

Kemenkes RI (2021) 'Infeksi Emerging Kementerian Kesehatan RI', Infeksi Emerging. Available at: https://infeksiemerging.kemkes.go.id/das hboard/covid-19.

Pemerintah Indonesia (2007) 'Peraturan Menteri Dalam Negeri Nomor 7 Tahun 2007 tentang Pedoman Pengelolaan Desa'. Jakarta.

Pemerintah Indonesia (2012) Undang-Undang Nomor 12 Tahun 2012 tentang Pendidikan Tinggi. Jakarta.

Rae Febrian, M. et al. (2020) 'Analisis Implementasi Penyelenggaraan Promosi Kesehatan Rumah Sakit di Era Jaminan Kesehatan Nasional Analysis of
Implementation of Hospital Health Promotion Implementation in the Era of National Health Insurance', Jurnal Ilmiah Kesehatan Masyarakat, 12(1), p. 20. Available at:

https://jikm.upnvj.ac.id/index.php/home /article/view/49.

Rojali (2019) 'Deteksi Dini Penyakit Tidak Menular Sebagai Germas di Rukun Warga 11 Kelurahan Kebanyoran Lama Jakarta Selatan Tahun 2019', 1(1), pp. 33-39.

Sutoro, E. (2002) Pemberdayaan Masyarakat Desa. Samarinda: Badan Diklat Provinsi Kaltim.

Suwondo, K. (2005) Civil Society di Aras Lokal. Yogyakarta: Pustaka Pelajar.

Usman, S. (2004) Pembangunan dan Pemberdayaan Masyarakat. Yogyakarta: Pustaka Pelajar.

WHO (2020) 'Pertanyaan Jawaban Terkait COVID-19 Untuk Publik'. Available at: https://www.who.int/indonesia/news/n ovel-coronavirus/qa-for-public. 